\title{
Dinamika Amonium dan Nitrat Pada Lahan Sawah Semi Organik untuk Tanaman Padi Lokal dan Hibrida di Subak Jatiluwih Kabupaten Tabanan
}

\author{
KHOSNUL KHOTIMAH, ANAK AGUNG NGURAH GEDE SUWASTIKA*), \\ DAN I WAYAN DANA ATMAJA
}

Program Studi Agroekoteknologi, Fakultas Pertanian, Universitas Udayana

J1. PB. Sudirman, Denpasar 80231 Bali

${ }^{*}$ E-mail: agungsuwastika@yahoo.co.id

\begin{abstract}
Dynamics Of Ammonium And Nitrate In Semi Organic Rice Fields For Local And Hybrid Rice Plants In Subak Jatiluwih, Tabanan Regency. The study was conducted to determine the dynamics of ammonium and nitrate and time subsequent fertilization in paddy fields with local and hybrid rice. Soil and water samples in two replications were taken each the two paddy fields periodically, namely during the tillage (DTT), $0,7,14,21,28,42,56,70,84,98$, and 112 days after planting (DAP). Ammonium and nitrate levels were analyzed by Macro Kjeldahl method. The results showed that the dynamics of ammonium and soil nitrate were different in two rice varieties. The highest ammonium content of local rice at the age of 7 DAP rice and the highest nitrate content at age 14 DAP. Ammonium and nitrate levels are highest in hybrid rice fields at 28 DAP rice age. The lowest ammonium and nitrate levels in two different varieties of rice land, namely the lowest local rice varieties at the age 28 DAP, whereas in hybrid rice land at age of 98 DAP. The results of this study indicate that supplementation of urea can be carried out at the age of 21 and 98 DAP for local rice varieties, and at the age of 14 DAP and 42 DAP for hybrid rice varieties.
\end{abstract}

Keywords: ammonium and nitrate dynamics, hybrid paddy, local paddy, rice field.

\section{PENDAHULUAN}

Indonesia merupakan salah satu negara penghasil padi di Asia. Varietas padi lokal dan hibrida masing-masing memiliki sifat yang berbeda yaitu umur tanaman, tinggi, bentuk, jumlah anakkan serta produksinya.Perbedaan demikian dapat mempengaruhi pengangkutan dan akumulasi unsurhara dari dalam tanah khususnya unsur hara nitrogen (Satoto et al., 2009).

Nitrogen merupakan unsur hara yang dibutuhkan dalam jumlah paling banyak bagi pertumbuhan tanaman tetapi ketersediannya tidak selalu mencukupi di dalam 
KHOSNUL KHOTIMAH. et al. Dinamika Amonium dan Nitrat Pada Lahan Sawah Semi Organik...

tanah.Tanaman menyerap nitrogen Lingkungan, Fakultas Pertanian Universitas dalambentukkation $\mathrm{NH}_{4}^{+}$dan anion $\mathrm{NO}_{3}^{-}$. Udayana.

Kedua ion tersebutberturut-turut dihasilkan dari proses amonifikasi dan nitrifikasi (Havlin et al.,2004).

Lahanpadi sawah dengan ekosistem tergenang menyebabkan kondisi distribusi oksigen pada setiap lapisan tanah berbeda- beda.Semakin dalam lapisan tanah maka jumlah oksigen akan berkurang. Kondisi ini menyebabkan pada lahan sawah terbentuknya lapisan tanah teroksidasi dan tereduksi yang memungkinkan adanya proses amonifikasi dan nitrifikasi.Kondisi ini menyebabkan permasalahan terkait dengan penggunaan pupuk nitrogen yang kurang effisien. Suwastika., dkk (2018) menyatakan, efisiensi pupuk nitrogen di lahan sawah pada umumnya masih rendah, sekitar 20-30\%. Penelitian ini bertujuan untuk mengetahui dinamika amonium dan nitrat pada lahan sawah organik dan mengetahui waktu pemberian pupuk susulan berdasarkan dinamika amonium dan nitrat.

\section{BAHAN DAN METODE}

\section{Waktu dan Tempat Penelitian}

Penelitian dilaksanakan pada bulan Juli 2018- Maret 2019, di Subak Jatiluwih, Kabupaten Tabanan, analisis sampel penelitian dilakukan di Laboratorium Ilmu Tanah dan

\section{Bahan dan Alat}

Bahan yang digunakan dalam penelitian ini adalah sampel tanah dan air. Bahan-bahan kimia yang digunakan untuk analisis kadar nitrat, amonium, pH tanah. Alat yang digunakan dalam penelitian ini adalah alat tulis kantor, kamera, kertas label, botol plastik, kantong plastik, kaleng susu yang telah diberi lubang pada kedua sisi atas dan bawah, pH meter, Makro Kjeldahl, alat-alat gelas, dan oven.

\section{Rancangan Penelitian}

Penelitian ini adalah penelitian eksploratif untuk mengevaluasi sistem budidaya padi sawah lokal dan hibrida yang dibudidaya secara semi organik. Evaluasi dilakukan terhadap hubungan antara faktor pembeda dengan dinamika amonium dan nitrat.

\section{Pelaksanaan Penelitian}

Pelaksanaan penelitian diawali dengan survei lapang untuk menentukan lokasi penelitian di Subak Jatiluwih. Lokasi petakan sampel ditentukan secara purposif. Ditentukan lokasi sampling pada 4 petakan yang memiliki sifat tanah dan sejarah 
penggunaan lahan yang relatif sama. Setiap 2 petakan ditanami padi lokal (cicih) dan 2 petakan ditanami padi hibrida (Ciherang). Petakan masing-masing ditentukan 5 titik sampel kemudian dikompositkan menjadi 1 sampel. Prosedur pengambilan sampel tanah dan air dilakukan sebagai berikut. (1) Pada titik sampel dibenamkan sedalam $30 \mathrm{~cm}$ kaleng susu yang telah diberi lubang pada kedua sisi atas dan bawah. (2) Pengambilan sampel air dilakukan pada kaleng yang telah dibenamkan dengan menggunakan spite, kemudian dimasukkan ke dalam botol plastik; (3) Pengambilan sampel tanah dilakukan pada kedalaman $30 \mathrm{~cm}$, kemudian dimasukkan ke dalam kantong plastik; (4) Pengambilan sampel tanah dilakukan sejak pengolaan tanah hingga menjelang panen terutama pada waktu 0,7 , 14 hari dan selanjutnya akan dilaksanakan tiap 2 minggu, sedangkan pengambilan sampel air dilakukan sepanjang masih ada air selama periode tanam.

\section{Pengukuran Parameter}

Pengukuran kadar N-amonium dan Nnitrat diukur dengan menggunakan metode Makro Kjeldahl. Reaksi tanah diukur dengan pH meter, sedangkan kadar air tanah ditetapkan secara gravimetri.

\section{Analisis Data}

Data yang diperoleh kemudian ditabulasi dan dianalisis secara statistika dengan menggunakan SPSS. Hasil tabulasi ditampilkan dalam bentuk grafik garis kontinyu.

\section{HASIL DAN PEMBAHASAN}

Padi lokal dan padi hibrida memiliki perlakuan pemupukan yang sama baik itu dosis, jenis, dan waktunya. Jenis pupuk yang diberikan oleh petani berdasarkan hasil wawancara yaitu pupuk kandang sapi diberikan pada masa olah tanah (OT) sebanyak 25 ton $\mathrm{ha}^{-1}$ dan pupuk urea diberikan pada umur $21 \mathrm{HST}$ sebanyak $50 \mathrm{~kg}$ $\mathrm{ha}^{-1}$. Hasil penelitian menunjukkan nilai $\mathrm{pH}$ minimum tanah padi local sebesar 6,24 yaitu tergolong agak asam pada umur 84 HST (Tabel 1). Nilai pH tanah maksimum yang ditanami padi hibrida yaitu 6,62 saat masa olah tanah (OT), sebaliknya untuk pH tanah minimum pada lahan sawah padi hibrida yaitu 6,21 (tergolong agak asam) yaitu saat umur 56 HST. Perubahan $\mathrm{pH}$ tanah dipengaruhi oleh penambahan bahan organik. Penambahan bahan organik yang belum matang atau yang masih mengalami proses dekomposisi, biasanya akan menyebabkan penurunan $\mathrm{pH}$ tanah, karena selama proses 
KHOSNUL KHOTIMAH. et al. Dinamika Amonium dan Nitrat Pada Lahan Sawah Semi Organik...

tersebut akan dilepaskannya asam-asam organik sehingga pengasaman tanah ikut terjadi. Pemberian pupuk urea akan menurunkan $\mathrm{pH}$ tanah akibat adanya pelepasan $\mathrm{H}^{+}$dari reaksi nitrifikasi yaitu perubahan $\mathrm{NH}_{4}^{+}$menjadi $\mathrm{NO}^{-}$(Winarso, 2005). Hal ini sesuai dengan hasil penelitain yaitu terjadinya penurunan $\mathrm{pH}$ tanah setelah di aplikasikannya pupuk urea pada umur tanaman 21 HST.

Tabel 1. Derajat Kemasaman Tanah pada Padi Lokal dan Padi Hibrida

\begin{tabular}{ccc}
\hline \multirow{3}{*}{ Umur Tanaman } & \multicolumn{2}{c}{ pH Tanah } \\
\cline { 2 - 3 } & Padi Lokal & Padi Hibrida \\
\hline OT $_{\#}$ & 6,2 & 6,57 \\
$\mathbf{0}$ & 6,54 & 6,49 \\
$\mathbf{7}$ & 6,47 & 6,62 \\
$\mathbf{1 4}$ & 6,46 & 6,47 \\
$\mathbf{2 1}$ \# & 6,49 & 6,49 \\
$\mathbf{2 8}$ & 6,38 & 6,28 \\
$\mathbf{4 2}$ & 6,34 & 6,41 \\
$\mathbf{5 6}$ & 6,29 & 6,21 \\
$\mathbf{7 0}$ & 6,28 & 6,49 \\
$\mathbf{8 4}$ & 6,24 & 6,32 \\
$\mathbf{9 8}$ & 6,36 & 6,43 \\
$\mathbf{1 1 2}$ & 6,27 & 6,25
\end{tabular}

Keterangan: \# = pemupukan dengan pupuk kandang sapi 25 ton $\mathrm{ha}^{-1}$. $\# \#$ = pemupukan dengan pupuk urea $50 \mathrm{~kg} \mathrm{ha}^{-1}$.

Dinamika Amonium $\left(\mathbf{N H 4}^{+}\right)$dan lokal menunjukkan nilai yang cukup tinggi Nitrat(NO3־)

Hasil analisis sampel tanah terhadap dinamika amonium dan nitrat yang ditanami padi lokal dari masa olah tanah (OT) hingga umur 112 HST mengalami fluktuasi (Gambar 1). Kadar amonium dan nitrat pada tanah padi pada saat OT yaitu $8,90 \%$ (amonium) dan $6,59 \%$ (nitrat). Hal ini terjadi akibat tidak ada penyerapan unsur hara oleh tanaman sehingga proses yang terjadi adalah mineralisasi pupuk kandang serta jerami yang diberikan pada saat olah tanah. 


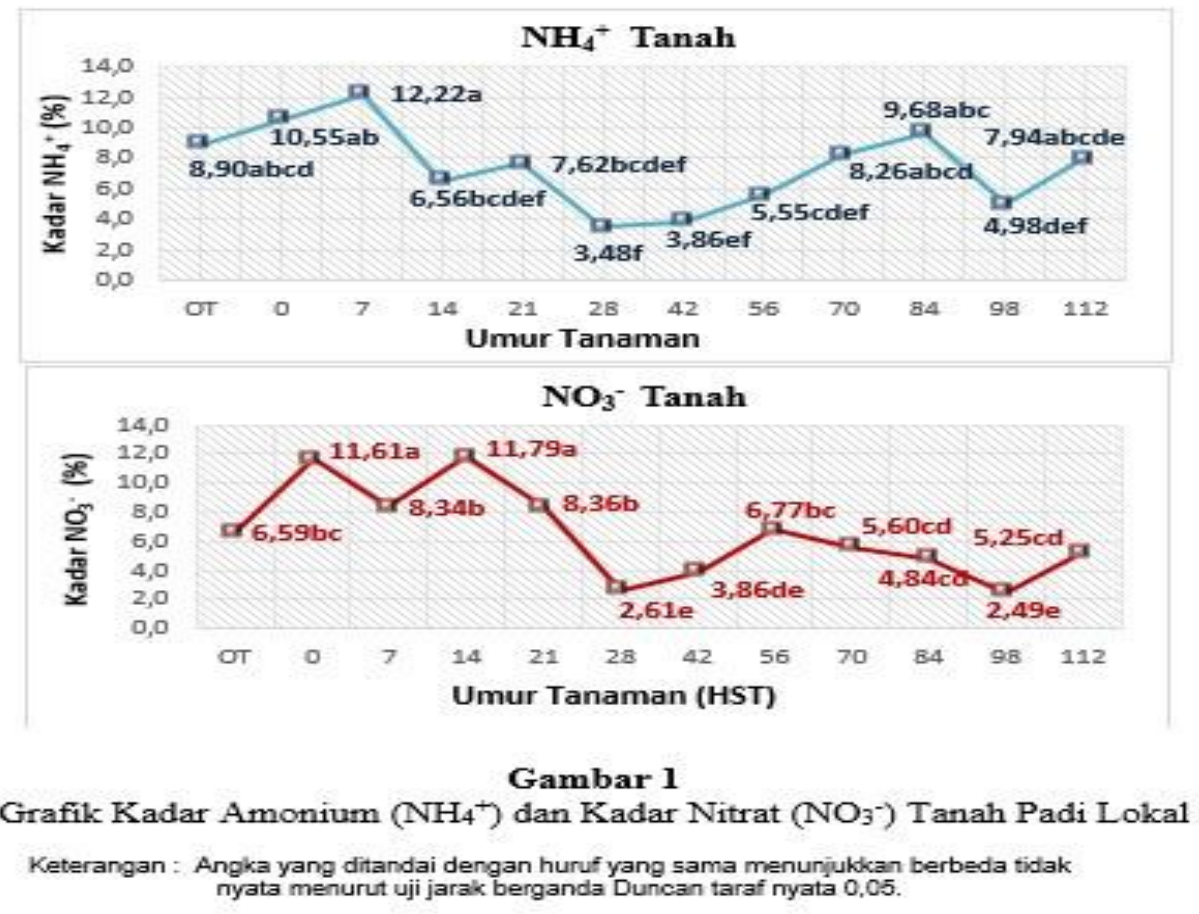

Kadar amonium dan nitrat mengalami penurunan terendah pada saat umur 28 HST yaitu kadar ammonium 3,48\% dan nitrat 2,61\%. Kadar ammonium dan nitrat yang mengalami penurunan diduga disebabkan oleh terjadinya proses nitrifikasi dan denitrifikasi secara bersamaan. Siklus nitrogen yang berkaitan dengan proses nitrifikasidenitrifikasi sangat ditentukan oleh mikroba tanah yang dipengaruhi kondisi lingkungan setempat, khususnya bahan organik, substrat nitrogen dan ketersediaan oksigen dalam 2). tanah (Nirliani, 2007; Suwastika et al., 2018).
Hasil analisis statistika menunjukkan bahwa pada kadar amonium tanah berbeda nyata antara umur 7 HST dan 28 HST, namun kadar nitrat anah pada setiap umur tanaman berbeda tidak nyata. Kadar amonium air terendah yaitu $0,07 \%$ terdapat pada umur 42 HST, sedangkan tertinggi yaitu $0,22 \%$ terdapat pada OT, 21 HST, dan 28 HST. Kadar nitrat terendah yaitu $0,12 \%$ terdapat pada OT, 7HST, dan 42 HST, sedangkan tertinggi yaitu 0,32\% terdapat pada umur 56 HST.(Gambar 
KHOSNUL KHOTIMAH. et al. Dinamika Amonium dan Nitrat Pada Lahan Sawah Semi Organik...

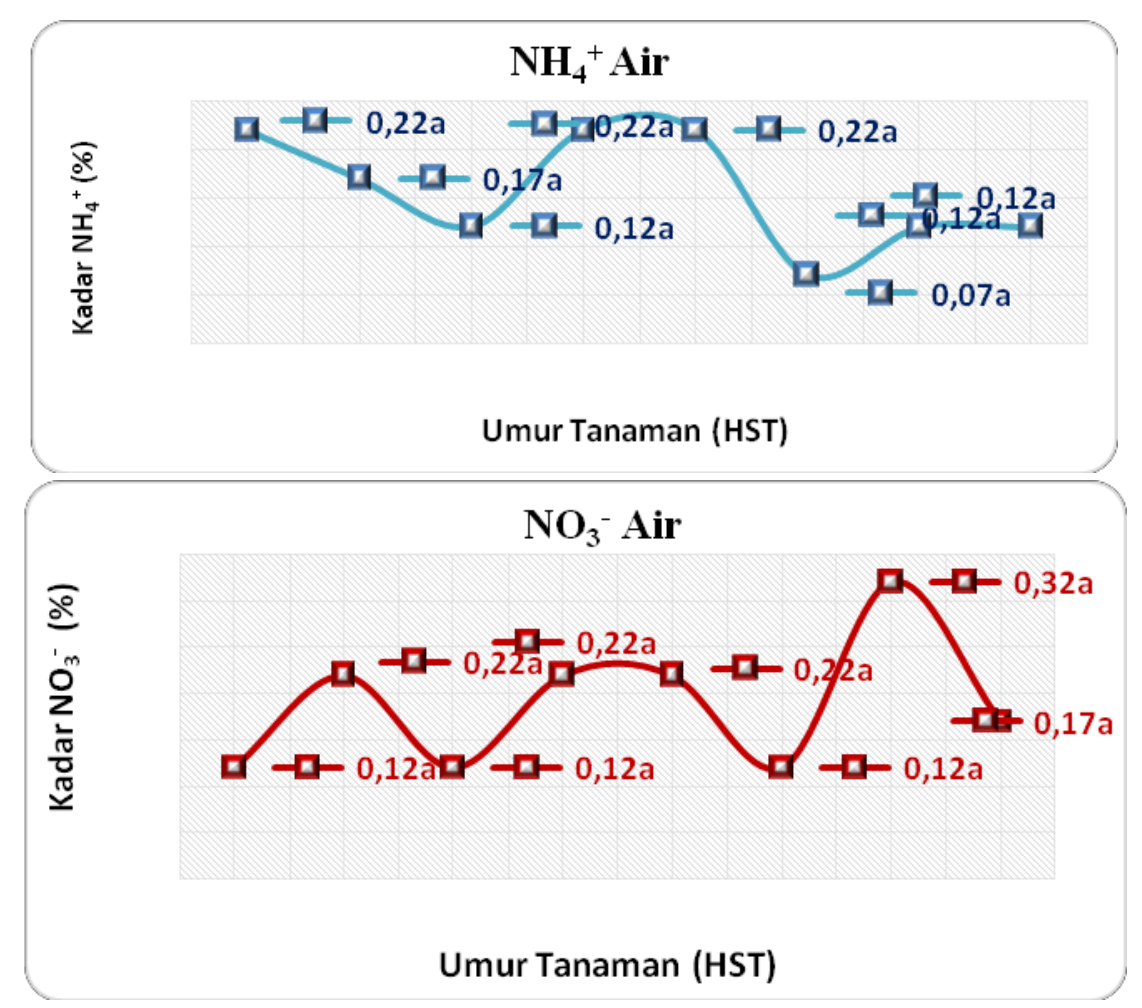

Gambar 2. Grafik Kadar Amonium $\left(\mathrm{NH}_{4}{ }^{+}\right)$dan Nitrat $\left(\mathrm{NO}_{3}{ }^{-}\right)$pada Air Padi Lokal Keterangan : Angka yang ditandai dengan huruf yang sama menunjukkan berbeda tidak nyata menurut uji jarak berganda Duncan taraf nyata 0,05 .

Kadar amonium dan nitrat lahan padi hibrida pada masa olah tanah (OT) yaitu $10,98 \%$ (amonium) dan 6,98\% (nitrat). Kadar amonium dan kadar nitrat menurun secara bersamaan pada saat masa penanaman yaitu umur tanaman padi 0 HST sejumlah $7,06 \%$ (ammonium) dan 4,40\% (nitrat). Penurunan kadar ammonium dan nitrat tersebut disebabkan adanya proses nitrifikasi dan denitrifikasi yang terjadi bersamaan. Kadar nitrat pada umur tanaman padi 7 HST sampai dengan 21 HST tidak terjadi penurunan maupun peningkatan yaitu $6,24 \%$ pada umur 7 HST, 6,14\% pada umur 14 HST dan 5,98\% pada umur 21 HST, sedangkan kadar amoniumpada umur tanaman padi antara 7 HST sampai dengan 21 HST terjadi penurunan yaitu $6,88 \%$ pada umur 7 HST, 4,09\% umur 14 HST dan mengalami peningkatan pada umur 21 HST yaitu 9,15\%. Penurunan kadar amonium dapat disebabkan karena adanya proses 
nitrifikasi yang terjadi, sedangkan umur tersebut telah memasuki fase peningkatan kadar amonium pada umur 21 primordia. Menurut Puji wibowo, (2010) HST disebabkan adanya difusi amonium varietas padi hibrida memasuki masa dari lapisan anaerobik menuju lapisan primordia pada umur 50 HST. Memasuki diatasnya yaitu lapisan aerobik. umur tanaman 70 HST didapatkan kadar Hardjowigeno \& Rayes amonium yaitu $5,73 \%$, nirtat $4,52 \%$ dan menyatakan bahwa kadar amonium yang kemudian pada umur tanaman 84 HST lebih tinggi pada lapisan bawah yang kadar amonium yaitu 5,75\% dan nitrat anaerobik dari pada lapisan atas yang 5,64\%. Rendahnya kadar amonium aerobik maka menyebabkan difusi amonium dibandingkan dengan kadar nitrat pada ke lapisan atas terus terjadi.

Kadar amonium dan nitrat mengalami umur tersebut menunjukkan adanya proses nitrifikasi yang terjadi. Terjadinya proses peningkatan saat umur 28 HST yaitu nitrifikasi tersebut tidak terlepas dari $15,27 \%$ (amonium) dan 11,61\% (nitrat), kondisi tanah yang tidak tergenang (aerob) peningkatan tersebut dikarenakan yaitu memungkinkan bakteri pelaku terjadinya proses hidrolisis pupuk urea nitrifikasi yang merupakan bakteri aerob yang diberikan pada saat umur tanaman dapat beraktivitas dengan baik. Kadar padi 21 HST sehingga memungkinkan amonium dan nitrat mengalami penurunan terjadinya proses nirifikasi. Kadar amonium terendah pada umur tanaman 98 HST yaitu dan nitrat kembali mengalami penurunan 3,11\% amonium dan 1,04 nitrat, pada umur 42 HST dan 56 HST, hal kemudian kadar amonium dan nitrat ini disebab adanya penyerapan unsur kembali meningat pada umur 112 HST yaitu hara oleh tanaman baik nitrogen dalam 6,84\% amonium dan 3,41\% nitrat. Kondisi bentuk amonium maupun nitrogen dalam tersebut disebabkan karena proses nitrifikasi bentuk nitrat karena padi hibrida pada dan denitrifikasi terjadi secara bersamaan. 
KHOSNUL KHOTIMAH. et al. Dinamika Amonium dan Nitrat Pada Lahan Sawah Semi Organik...

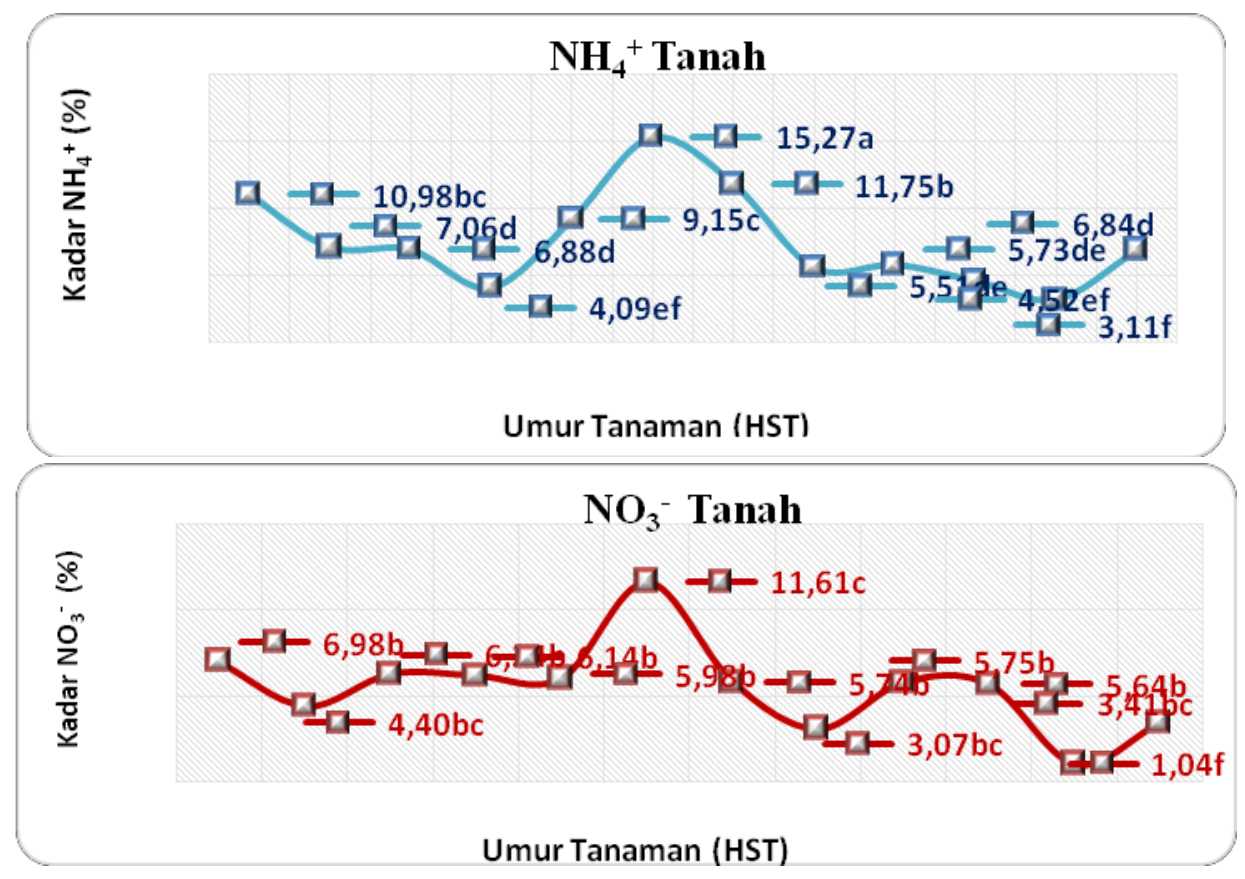

Gambar 3. Grafik Kadar Amonium $\left(\mathrm{NH}_{4}{ }^{+}\right)$dan Nitrat $\left(\mathrm{NO}_{3}{ }^{-}\right)$Tanah Padi Hibrida

Keterangan : Angka yang ditandai dengan huruf yang sama menunjukkan berbeda tidak nyata menurut uji jarak berganda Duncan taraf nyata 0,05 .

Hasil analisis statistika menunjukkan terendah yaitu $0,07 \%$ terdapat pada umur 0 bahwa kadar amonium tanah padi hibrida HST, sedangkan tertinggi yaitu 0,27\% berbeda nyata yaitu pada umur tanaman padi terdapat pada umur 14 HST. Kadar nitrat $28 \mathrm{HST}$, sama halnya pada umur padi $28 \mathrm{HST}$ terendah yaitu $0,12 \%$ terdapat pada $28 \mathrm{HST}$, terdapat beda nyata pada kadar nitrat tanah. sedangkan tertinggi yaitu 0,27 \% terdapat Kadar amonium air padi hibrida (Gambar 4) pada umur 0 HST. 


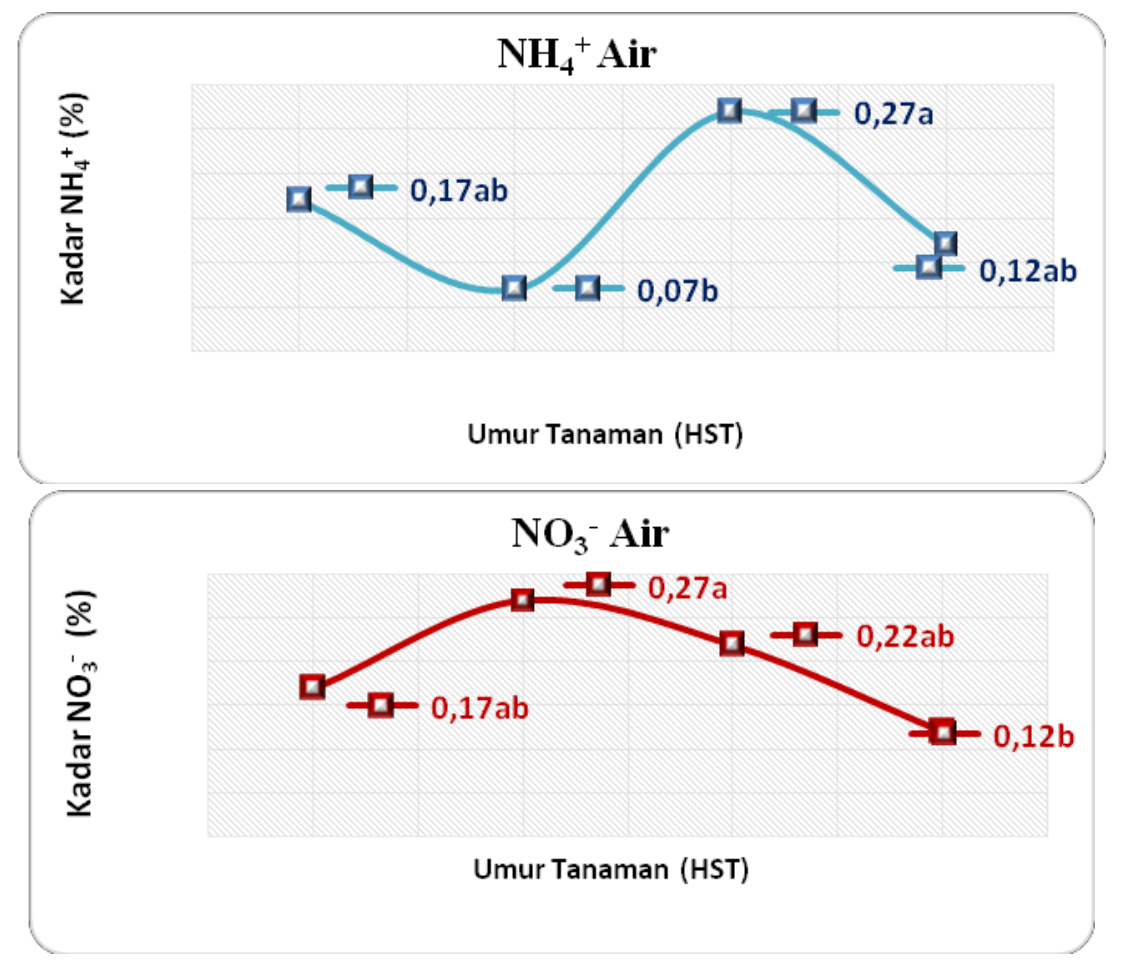

Gambar 4. Grafik Kadar Amonium (NH4 ) dan Nitrat (NO3 ) pada Air Padi Hibrida Keterangan : Angka yang ditandai dengan huruf yang sama menunjukkan berbeda tidak nyata menurut uji jarak berganda Duncan taraf nyata 0,05 .

\section{Waktu Pemberian Pupuk Susulan}

Hasil penelitian sampel tanah pada padi lokal menunjukkan kadar $\mathrm{NH}_{4}^{+}$ terendah yaitu saat umur tanaman 28 HST, pada uji beda nyata menunjukkan kadar $\mathrm{NH}^{+}{ }^{+}$tanah padi lokal umur 28 HST berbeda tidak nyata dengan umur tanaman 21 HST. Kadar $\mathrm{NO}^{-}{ }^{-}$terendah saat umur tanaman 28 HST dan 98 HST. Hasil penelitian sampel tanah yang ditanami padi hibrida kadar

amonium terendah yaitu pada saat umur 14 HST dan 98 HST, sedangkan pada kadar nitrat yaitu saat umur 56 HST dan 98 HST, namun dapat dilihat saat umur 42 - 56 HST kadar amonium dan nitrat tanah padi hibrida terlihat terus mengalami penurunan. Dilihat dari penurunan kadar amonium dan nitrat terendah pada penelitian ini, maka dapat di lakukan pemupukan urea susulan yaitu pada umur 21 HST dan 98 HST pada lahan padi 
KHOSNUL KHOTIMAH. et al. Dinamika Amonium dan Nitrat Pada Lahan Sawah Semi Organik...

lokal, sedangkan pada lahan padi hibrida pada saat umur tanaman 14 HST dan 42 HST.

\section{SIMPULAN}

Dinamika $\mathrm{NH}_{4}^{+}$dan $\mathrm{NO}_{3}^{-}$tanah pada kedua varietas padi berbeda pada penelitian ini. Pemupukan urea susulan untuk tanaman padi lokal dapat dilakukan pada saat umur 21 HST dan 98 HST, sedangkan pada padi hibrida yaitu pada umur 14 HST dan 42 HST.

\section{DAFTAR PUSTAKA}

Harjowigeno, S \& L Rayes. 2005. Tanah Sawah, Karakteristik, kondisi, dan permasalahan Tanah Sawah di Indonesia. Bayumedia Malang Jawa Timur.

Havlin, J. L., Beaton, J. D., Tisdale, S. L. \& Nelson, W. L. 2004. Soil Fertility and Fertilizers an Introduction to Nutrient Management. 7th Edition, Prentice Hall, USA.

Nirliani. 2007. Aktivitas Bakteri Denitrifikasi Asal Sawah di Bogor, Jawa barat, IPB, Bogor.

Puji, W. 2010. Pertumbuhan dan Produktivitas Galur Harapan Padi (Oriza Sativa. L) Hibrida di Desa Ketaon Kecamatan Banyudono Boyolali. Semarang.

Satoto, Suryanto B, \& Suprihatno B. 2009. Prospek Pengembanagan Varietas Padi Hibrida. Didalam Darajat AA. Editor. Padi Inovasi Teknologi Produksi. Sukamandi : Balai Besar Penelitian Tanaman Padi. Badan Penelitian dan Pengembangan Pertanian. Kementrian Pertanian.
Suwastika, A. A. N. G., N. N. Soniari, \&A. A. I. Kesumadewi. 2018. Biologi Tanah. Program Studi Agroekoteknologi Fakultas Pertanian Universitas Udayana, Bali.

Winarso, S. 2005. Kesuburan Tanah Dasar Kesehatan dan Kualitas Tanah. Gava Media. Yogyakarta. Hlm 42-44. 